\title{
SUB-SURFACE MELT POOLS IN THE MGMURDO ICE SHELF, ANTARCTICA
}

\author{
By R. A. PAIgE \\ (U.S. Naval Civil Engincering Laboratory, Port Hueneme, California 9304 I, U.S.A.)
}

\begin{abstract}
Aвstracr. Sub-surface melt pools were discovered during construction of an airfield located on glacier ice in the western part of the McMurdo Ice Shelf, Antarctica. The melt pools occur beneath areas of blue glacier ice and they are impossible to detect by visual examination. They vary in size and shape but are usually 1.0 to $\mathrm{t} .5 \mathrm{~m}$ deep and span circular areas 10 to $15 \mathrm{~m}$ in diameter. Sub-surface melting starts in midDecember at depths of $40 \mathrm{~cm}$ or more and it progresses until late January when refreczing begins. The ice cover over melt pools may thin to as little as $7 \mathrm{~cm}$ and this creates a serious hazard to aircraft operations.

The melt pools are caused by the greenhouse effect of intense solar radiation, low albedo of the blue glacier ice and heat absorption by rock particles and dust. The high-albedo layer of chipped ice and powdered ice that was produced during runway construction was completely successful in preventing sub-surface melting. The thickness of this protective layer appeared to be of little importance, providing it exceeded $3 \mathrm{~cm}$.
\end{abstract}

RÉsumé. Poches de fonte sous-glaciaire du McMurdo Ice Shelf, Antarctique. Des eaux de fonte étaient découvertes dans la couche inférieure de la glace de glacier au cours de la construction d'un aèrodrome dans la partie ouest de McMurdo Ice Shelf, Antarctique. Les eaux de fonte se trouvaient au-dessous des étendues de glace bleue de glacier et il est impossible de les découvrir par examen visuel. Elles varient en volumes et formes, mais elles avaient généralement de 1 à $1,5 \mathrm{~m}$ de profondeur et de 10 à $15 \mathrm{~m}$ de diamètre. La fusion dans la couche inférieure commence mi-decembre à la profondeur de $40 \mathrm{~cm}$ ou plus, et s'accroit jusqu'à la fin de janvier quand le regel commence. La couverture de glace au-dessus des eaux de fonte peut s'amincir à $7 \mathrm{~cm}$ et devient un risque séricux aux operations ac̀riennes.

Les eaux de fonte sont les résultats de l'effet de serre de la radiation solaire intensive, la faible albédo de la glace bleue de glacier et l'absorption de chaleur par les particules de roche et poussière. La couche de forte albédo de glace éclatée et pulverisée, que l'on produit au cours de la construction de la piste, prévient complètement la fusion dans la couche inféricure. L'épaisseur de cette couche protective a peu d'importance tant qu'elle dèpasse $3 \mathrm{~cm}$.

Zusammenfassung. Schmelzlöcher unter der Oberfläche im MeMurdo Ice Shelf, Antarktika. Beim Bau eines Flugfeldes auf dem Gletschereis des westlichen McMurdo Ice Shelf, Antarktika, wurden Schmelzlöcher unter der Oberfläche entdeckt. Die Schmelzlöcher treten unter Gebieten mit blauem Gletschereis auf und sind durch blossen. Augenschein nicht auszumachen. Sie variieren in Grösse und Gestalt, sind aber gewöhnlich $1,0-1,5 \mathrm{~m}$ tief und nehmen Kreisflächen von 10-15 m Durchmesser cin. Das Schmelzen unter der Oberflache beginnt Mitte Dezember in mindestens $40 \mathrm{~cm}$ Tiefe und hält bis spät in den Januar an, wo das Gefrieren wieder einsetzt. Die Decken der Schmelzlöcher können bis auf den kleinen Betrag von $7 \mathrm{~cm}$ abnehmen, womit cine ernste Gefahr für den Flugbetrieb entsteht.

Die Schmelzlöcher entstehen durch den Treibhauseffekt intensiver Sonneneinstrahlung, die geringe Albedo des blauen Gletschereises und die Wärmeabsorption durch Gesteinssplitter und Staub. Die Schicht mit starker Albedo aus abgehobeltem und pulverisiertem Eis, die beim Bau der Landebahn entsteht, ergab einen vollkommenen Schutz gegen das Schmelzen unter der Oberfläche. Die Dicke dieser Schutzschicht erwies sich von geringer Bedeutung, vorausgesetzt, dass sie $3 \mathrm{~cm}$ überstieg.

\section{INTRODUCTION}

Sub-surface melt pools occur beneath blue glacier ice in the western part of the McMurdo Icc Shelf, Antarctica. In the austral summer of $1965-66$, a reconnaissance of this area for an alternative airfield disclosed several melt pools; however, their full extent was not realized at that time. During construction of the "Outer Williams Field" alternative airfield, these melt pools were found to extend throughout the proposed runway area and they presented a serious hazard to aircraft traffic.

In "Dcep Freeze 67", an investigation was initiated to determine the extent, seasonal history and cause of sub-surface melt pools in an effort to find the best means of preventing their occurrence within the runway area. This report describes the melt pools, their origin, the main factors contributing to their formation and the effectiveness of a chipped ice and snow surface in preventing their formation.

\section{Location and Physical Setting}

"Outer Williams Field"' is located on the vast, relatively smooth expanse of glacier ice in the western part of the McMurdo Ice Shelf at approximately lat. $77^{\circ} 57^{\prime} 40^{\prime \prime}$ S., long. $166^{\circ} 28^{\prime} 30^{\prime \prime}$ E. (Fig. 1). Access from McMurdo station to "Outer Williams Field" is provided by $22 \mathrm{~km}$ of compacted-snow road via Scott Base and the present Williams Field Air Facility (Fig. 2). 
The airfield is west of a transitional climatic zone where the annual budget changes from positive to negative. To the east of this zone, accumulation exceeds ablation; to the west, ablation exceeds accumulation and the glacier surface is partially free of snow throughout most of the summer and fall (Paige, r 966 , p. 6). Little is known concerning the local climate in the western part of the ice shelf except that the intensity of melting and ablation increases westward towards Victoria Land.

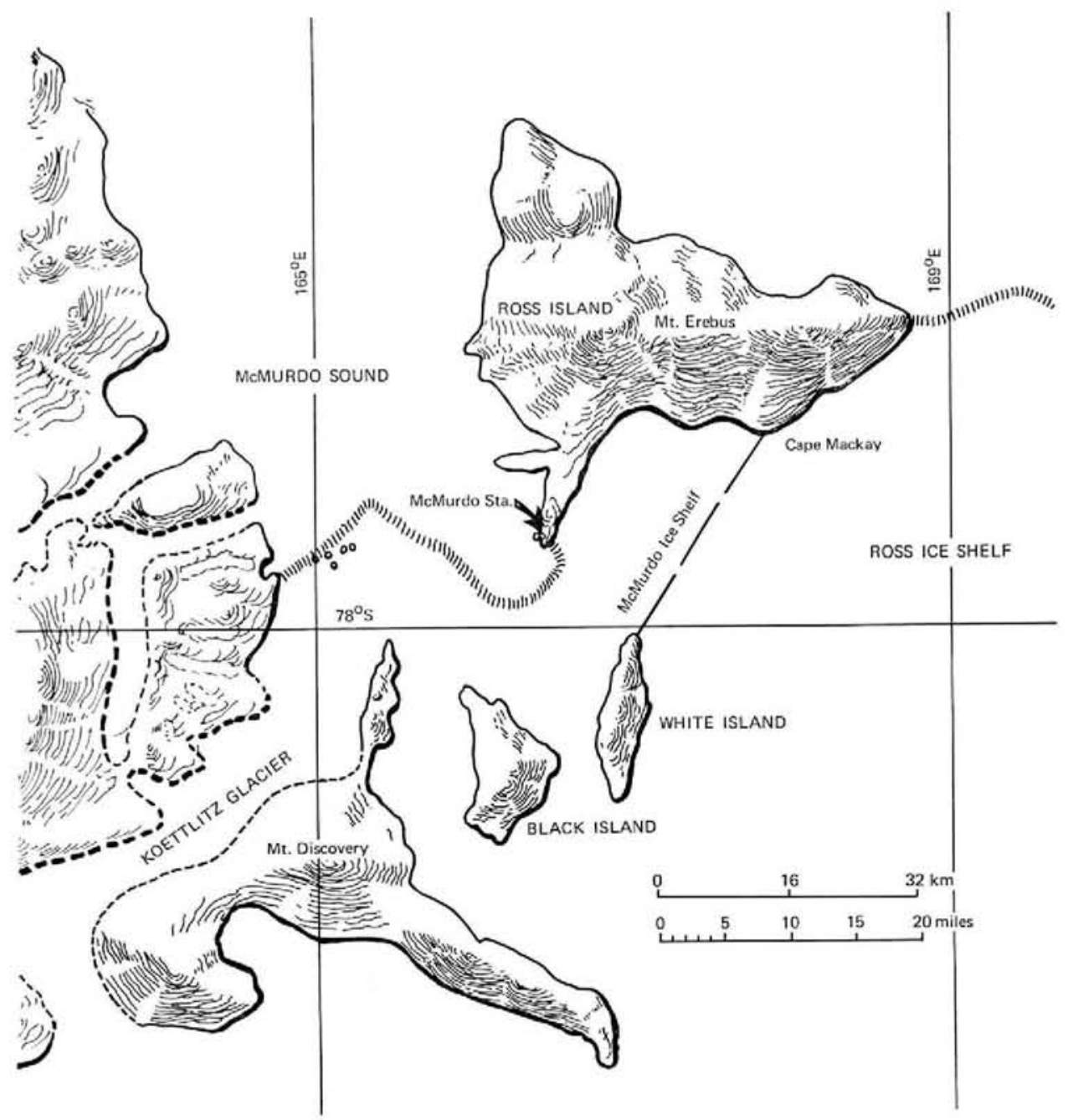

Fig. 1. Index map of the McMurdo Sound region, Antarctica.

\section{Description of Melit Pools}

The sub-surface melt pools occur throughout an elongated, poorly defined, $\mathrm{I}_{10-\mathrm{km}^{2}}$ area that trends north-south in the western part of the McMurdo Ice Shelf. The glacier surface in this area has a mottled appearance caused by thin, patchy snowdrifts and low mounds of white bubbly ice distributed in a random pattern on clear, blue glacier ice. The melt pools are impossible to detect by visual examination but they occur exclusively beneath the blue ice. The topography of the area is relatively smooth with a northerly slope of only a few feet per mile and a subdued hummocky surface having a relative relief of 30 to $60 \mathrm{~cm}$. The melt pools vary widely in size and shape but they are generally 0.5 to $1.0 \mathrm{~m}$ 
deep and span circular or elliptical areas 10 to $15 \mathrm{~m}$ in diameter. Starting in mid-December, the ice over the melt pools decreases in thickness from 30 or $40 \mathrm{~cm}$ to as little as $7 \mathrm{~cm}$ by mid-January and it may not support even lightweight tracked vehicles. Farther to the west towards Victoria Land, surface melt features become increasingly common in the form of open melt pools and surface melt-water run-off.

The sub-surface melt pools alternate with low, gently rounded mounds of white bubbly ice. These ice mounds are seldom more than $60 \mathrm{~cm}$ high and span a circular area varying from $2 \mathrm{~m}$ to more than

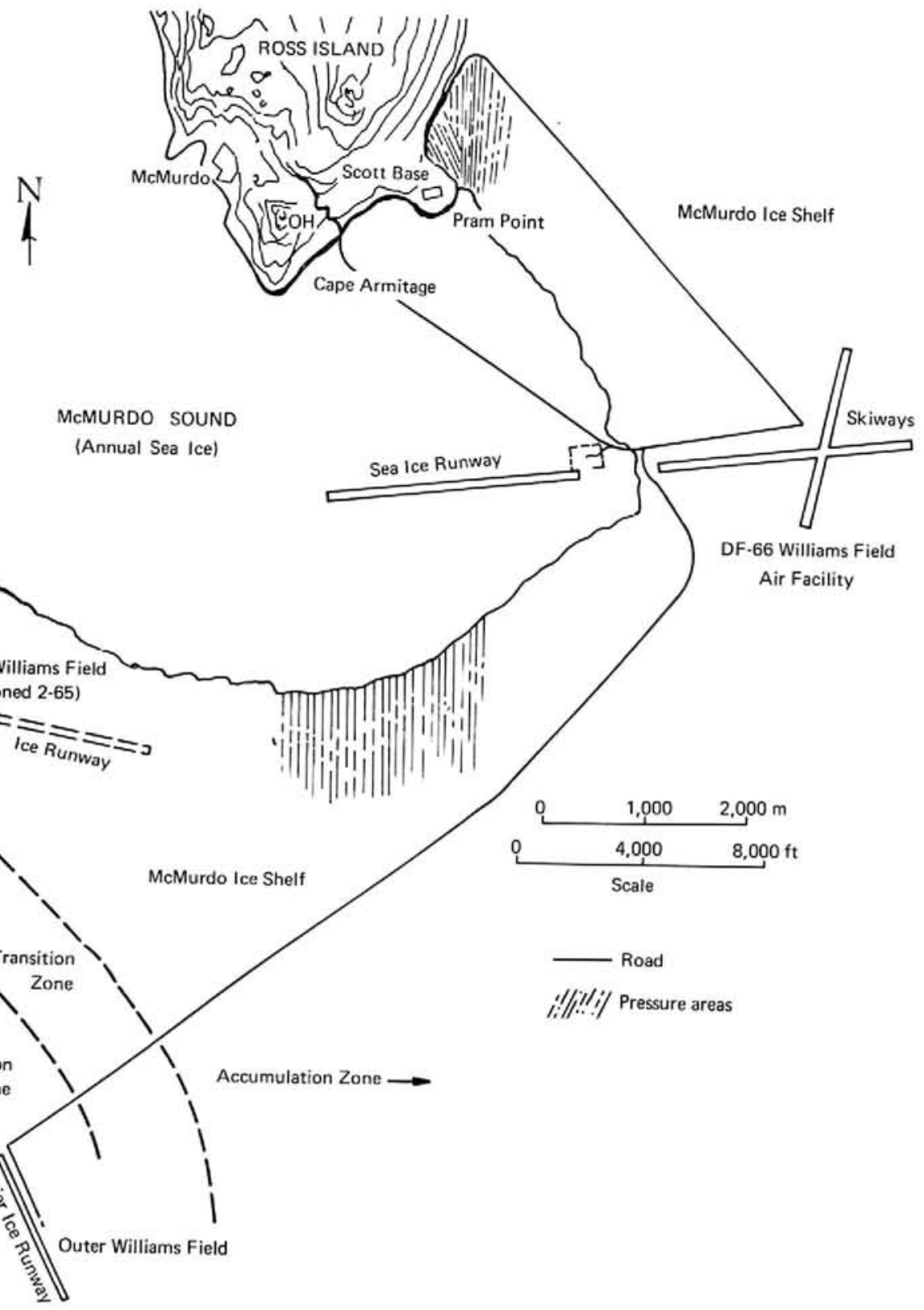

Fig. 2. Sketch map of the McMurdo station to "Outer Williams Field" area. 
$8 \mathrm{~m}$. Cailleux ( $1962, \mathrm{p}$. ${ }^{3} \mathrm{3}^{2}$ ) has described similar mounds forming on small lakes elsewhere in the McMurdo Sound region. "The ice mounds are similar in many respects to pingos that occur in permafrost regions of the Arctic (Mullex, 1947, p. 59) and here they are termed icc pingos.

\section{Origin of the Melt Pools}

'The melt pools are caused by the greenhouse effect of intense solar radiation, low albedo of the blue glacier ice, and heat absorption by dark objects. Sub-surface melting begins in mid-December and it consists of intergranular moisture as evidenced by moist auger cuttings. This initial melting, which usually occurs at depths of $40 \mathrm{~cm}$ or more, may or may not be associated with the presence of dirt. As melting progresses, a lenticular pool forms with sub-surface boundaries detcrmined by the surface configuration of snowdrifts and ice pingos. Melting progresses both upwards and downwards, and eventually the ice cover over the sub-surface pool decreases to as litule as $7 \mathrm{~cm}$, and the total depth may reach $1 \mathrm{~m}$.

As winter approaches, the melt pools begin to refreeze and the enclosed water is trapped under increasing hydrostatic pressure. Eventually, this pressure is relieved cither when the entire rool of the melt pool is uplifted to form an ice pingo or when cracking releases the watcr as a surfacc flow. Tension cracks radiating from the center of the mound devclop and release any remaining water.

The surface features throughout the vast mclt-pool area ncar "Outer Williams Field" constantly change in response to the seasons. Melt pools that form during the summer may become ice pingos the following winter. The effects of sublimation, melting and wind may eventually reduce the topographic expression of an ice pingo so that it once again becomes a melt pool.

'The sub-surface melt pools appear to be a leature unique to the western part of the McMurdo Foc Shelf. Reports of similar features are rare in the literature and describe various melt phenomena occurring on frozen lakes or bay icc clsewhere in Antarctica. Some of the ice monnds described by Cailleux ( 1962, p. 13 1,132 ) have been studied by the author and they were found to be ice pingos resulting from the refrcczing of sub-surface melt pools identical to those near "Outer Williams Field".

Van Autenboer ( 1962, p. 351 ) has described ice mounds on a large frozen lake in the Sor-Rondane, Antarctica, that appear to be identical to those in the McMurdo Sound region and probably lormed by the same process. He has also described other melt phenomena ( $\mathrm{p} .352$ ) that are common on the McMurdo Ice Shelf, espccially ncar Black Island and west of "Outer Williams Field".

Takahashi ([1960], P. 322) has described melt pools that occur in snow and snow-ice deposited on saline bay ice of the Prins Olay Kyst of Antarctica. These melt pools are similar in size and shape to those in the McMurdo Ice Shelf and they are often concealed by a crust of ice and snow (p. 323, 325). Their origin is attributed predominantly to the effects of solar radiation and the absorptivity differences of snow and icc (p. $326,33^{\circ}$ ), although high ambient temperaturcs and warm winds are also considered. Other sub-surface melt pools and icc mounds probably occur under similar climatic conditions elsewhere in Antarctica but they have not yet bocn discovered or reported.

\section{Factors affecting Sub-surface Melting}

A combination of factors, such as solar radiation, albedo, clark-colored rock particles in the ice, air temperature and the presence or abscnce of snow, contribute, with varying degrees of importance, to sub-surface melting. Of these factors, solar radiation, albedo and the presence or absence of snow probably have the greatest effect.

\section{Solar Radtation}

Solar-radiation energy is probally the single mcst impertant factor contributing to sub-surface melting. Glaciological studies in Alaska show that solar radiation furnishes at least 75 per cent of the energy required to melt ice (Mayo and Péwé, 1963, p. 640). Sagar (1962, p. 18, 19) has stated that radiation is of prime importance to the ablation season in the central Arctic. Solar-racliation data for the McMurdo Sound region have been presented by Thompson and Macdonald (1962). 'I hese data show a high percentage of sunshine and high-intensity radiation that approaches $105 \mathrm{~kJ} / \mathrm{cm}^{2}$ in mid-summer (p. 887, 880). 
At.Bedo

The reflectivity, or albedo, of the surface regulates the heat energy absorbed and it is as important as solar radiation in causing various melt features on glaciers. Diurnal and seasonal albedo variations are common and they are caused by solar angle, color, grain form, solid impurities (Mellor, 1964, p. 93), surface roughness, melting and refreezing, and cloud cover (Diamond and Gerdel, r956, p. 5).

\section{Albedo of snow}

Freshly fallen snow, or fine-grained drift snow, probably has the highest albedo of any natural substance. Published values vary from 70 to 95 per cent but they are mostly above 80 per cent (Mantis, 195I, p. 64, 66; Diamond and Gerdel, 1956, p. 5, 6). Measurements over newly fallen snow near Williams Field gave an albedo of 86 per cent. As snow ages, the albedo decreases because of changes in grain-size, color and density (Mantis, 1951, p. 64; Chernigovskiy, 1966, p. 154-57). Melting and refrcezing forms an icy surface that also increases the absorption and scattering of solar energy. The presence of a light, finc-grained snow cover, even if thin, affords considerable protection against solar radiation.

\section{Albedo of ice}

The albedo of ice is considerably less than that of snow and it is affected largely by color, impurities and the presence or absence of melt water. Chernigovskiy (1966, p, 162) has reported albedo values from 72 per cent (probably for clean white ice) to 36 per cent for blue ice beneath melt water. Lyons and Stoiber (1959) have stressed the difference between flawless ice and bubbly ice in measuring the adsorption (p. 11) of various wavelengths of energy. They have further stated (p. 8) that the energy absorbed by bubbly ice is as much as twice that absorbed by flawless ice. Air bubbles are common in glacier ice, especially in the vicinity of "Outer Williams Field", where the ice above and below the melt pools is quite bubbly and has a density of only $0.88 \mathrm{Mg} / \mathrm{m}^{3}$. Also, the ice associated with the melt pools was deep blue or aquamarine and had an albedo of $4^{8}$ per cent.

\section{EFfects of DiRt in IGE ANd SNow}

The presence of dirt or other dark contaminant lowers the albedo, absorbs heat and accelerates melting. Dirt of volcanic origin is common in the ice and snow at "Outer Williams Field". This material is transported by high winds from Black Island and Brown Peninsula, and it has a size distribution ranging from fine dust up to particles $6 \mathrm{~mm}$ in diameter. The bubbly glacier ice at "Outer Williams Field" contains isolated grains or thin discontinuous layers and lenses of dirt throughout at least the upper $2 \mathrm{~m}$ of ice. Also, the bottoms of many melt pools have a thin layer of dark mud and sand, usually at depths of 1.0 to $1.5 \mathrm{~m}$.

\section{Prevention of Sub-surface Melting}

Sub-surface melting does not begin until carly or mid-December, and refreezing begins in late January; the maximum period of sub-surface melting is therefore to to 12 wecks. A high-albedo surface layer with some insulating properties is needed to protect the underlying ice from intense solar radiation during this short period.

The runway at "Outer Williams Field" was prepared for use by leveling and smoothing the surface with wheel-mounted pulvimixers. Pulvimixing produces a layer 7 to $15 \mathrm{~cm}$ thick consisting of chipped ice and powdered ice mixed with snow. This white, dense layer had an albedo of 76 per cent, and it was completely effective in preventing the formation of melt pools within the runway area.

Patches of bare ice caused by high winds or traffic occasionally developed on the runway. Sub-surface melting quickly occurred under many of the larger bare areas but no distinct voids cver formed. Subsurface melting beneath large, semi-stable snowdrifts or pulvimixed ice was not detected at any time during the summer of "Deep Freeze 67" or "Deep Freezc 68". The thickness of snow or pulvimixed ice seemed to make little difference in preventing sub-surface melting provided that the snow or ice cover was more than $3 \mathrm{~cm}$ thick.

\section{Conclusions}

It is apparent that the sub-surface melting in the vicinity of "Outer Williams Field" is controlled by a delicate balance between solar radiation, albedo, snow cover, and air and ice temperatures. Less than 
$2 \mathrm{~km}$ to the cast, melting does not occur and snow accumulation begins to exceed ablation. Only $6.5 \mathrm{~km}$ to the west, surface melting and surface melt-water run-off predominate over sub-surface melting, and ablation grcatly exceeds accurnulation. The delicacy of this balance is further demonstrated by the fact that a relatively thin, high-albedo layer is all that is required to prevent sub-surface melting.

MS. received 29 Afril 1968

\section{REFERENCES}

Aurenboer, T. van. 1962. Ice mounds and melt phenomenat in the Sor-Rondane, Antarctica. Fonmal of Glaciology, Vol. 4 , No. 33 , p. $349-54$.

Cailleux. A. Ig62. Ice mounds in frozen lakes in McMurdo Sound, Antarctica. Foumal of Glaciology, Vol. 4, No. 31, p. 13 I-33.

Chernigovskiy. N. Ii. 1966 . Radiational propertics of the central Aretic jce coat. (In Soviel data on the Aretic heat budgef and its clinalic inglkence. Santa Monica. Calif., Rand Corp. p. 151-72. (Memorandum RM5003oPR.))

Diansund, M., and Gerdel, R. W. 1956. Radiation measurements on the Greenland ice cap. U.S. Snowe, Ice and Permafrost Research Establistment. Research Refort ig.

Lyons, J. B., and Stoiber, R. 1). 1959. The abrorptivity of ice : a critical review. Hanover, New Hampshire, Dartmouth College. (AFCRC-TX-59-656, Scientific Report No. 3, contract AF 19(604) 2159-)

Mantis, II. T., ed. 1951. Review of the propertics of snow and ice, with reports by H. Bader, C. S. Benson, P. P. Bey, R. H. Doherty, R. J. Goldstein, J. A. Joseph, S. W. Rasmussen, D. C. Schiavone. U.S. Snowe, Ice and Permafrast Research Eslailishmenl. Repori 4.

Mayo. I.., and Péwé, T. L. 1963 . Ablation and net total radiation, Gulkana Glacier, Alaska. (In Kingery, W. D., ed. Ie and snow; properties, processes, and applications: proceedings of a conference held al the Massachusetts lnstitute of Technology, Febriary 12 16. 1962 . Cambridge, Mass., M.I.I. Press, p. 633 43.)

Mellor, M. 1964. Snow and ice on the Earth's surface. U.S. Cold Regions Research and Engineering Laboratory. Cold regions science and enuineering. Hanover, N.H., Pt. II, Sect. C.

Muller, S. W., comp. 1947. Pernafrast, or permanenlly frozen ground. and related engineering problems. Ann Arbor, Mich., J. W. Edwards, Inc.

Paige, R. A. 1966 . Ice and snow tcrain features- McMurdo station, Antarctica. U.S. Naval Civil Engineering Laboratory, Port Hteneme, Calif. Techrical Note N-840.

Sagar. R. B. 1962 . Meteorological and glaciological studics. Ice Rise station, Ward Hunt Island, May to September 1460. Arctic Institute of Worth America. Scientific Reporl No. 5 .

Takabashi. Y. [1960.] On the puddles of Lutrow-Holm Bay. (In Antarclic meteorology. Procedings of the symposium heid in Melboxme, Febriary 1959. London. New York. Pergamon Press, p. 32 I-32.)

Thompson, D. C., and Macdonald, W. J. P. 1962. Radiation measurements at Scott Base. New Zedand Journal of Geology and Geophysics, Vol. 5, No. 5, p. 874-9og. 